\title{
An extinct hummingbird species that never was: a cautionary tale about sampling issues
} in molecular phylogenetics

3

\author{
Jorge L. Pérez-Emán ${ }^{1, *}$, Jhoniel Perdigón Ferreira ${ }^{1, \varnothing}$, Natalia Gutiérrez-Pinto ${ }^{2, \otimes}$, Andrés M. Cuervo ${ }^{3}$, \\ Laura N. Céspedes ${ }^{2}$, Christopher C. Witt ${ }^{4}$, and Carlos Daniel Cadena ${ }^{2}$ \\ ${ }^{1}$ Instituto de Zoología y Ecología Tropical, Facultad de Ciencias, Universidad Central de Venezuela, Caracas, \\ Venezuela. \\ ${ }^{2}$ Laboratorio de Biología Evolutiva de Vertebrados, Departamento de Ciencias Biológicas, Universidad de los Andes, \\ Bogotá, Colombia. \\ ${ }^{3}$ Instituto de Investigación en Recursos Biológicos Alexander von Humboldt, Bogotá, Colombia. \\ ${ }^{4}$ Museum of Southwestern Biology, University of New Mexico, Albuquerque, New Mexico, USA. \\ ${ }^{\varnothing}$ Current address: Department of Evolutionary Biology and Environmental Studies, University of Zurich - Irchel. \\ ${ }^{\otimes}$ Current address: School of Biological Sciences, University of Nebraska - Lincoln. \\ *Author for correspondence (jorge.perez@ciens.ucv.ve).
}

\section{ABSTRACT}

The Bogota Sunangel (Heliangelus zusii) was described based on a historical specimen lacking locality data as a striking -and potentially extinct- new species of hummingbird more than two decades ago. However, it was considered a dubious taxon by some researchers until a molecular study with strong species-level taxon sampling revealed its phylogenetic affinities and validated its status as a distinct species. We reanalysed existing mitochondrial DNA data together with a new data set sampling multiple populations of the Long-tailed Sylph (Aglaiocercus kingii), a species broadly distributed in the Andes of South America. In contrast to previous work, we found that $H$. zusii shares a haplotype with specimens of $A$. kingii from the Eastern Cordillera of Colombia, which is phylogenetically nested within a clade formed by populations of $A$. kingii from the Colombian Andes. These results suggest that H. zusii is not a distinct species, but is most likely the result of hybridization between a female A. kingii and a male of another hummingbird species. These findings highlight the importance of thorough taxonomic and geographic sampling when assessing the likelihood of hybrid origin of an organism, particularly in cases potentially involving wide-ranging species in areas where deep phylogeographic structure is likely.

Keywords: Aglaiocercus, geographic sampling, Heliangelus zusii, hybridization, phylogeography.

\section{INTRODUCTION}

The selection of species and individuals for inclusion in molecular analyses critically affects inferences in various fields of systematic biology including phylogenetics [1], phylogeography [2], and species delimitation [3]. Especially in areas such as the Neotropical region where molecular analyses have recovered substantial within-species divergence and unexpected affinities of populations [4], biases resulting from incomplete taxonomic or geographic sampling may importantly compromise the results of analyses aimed at understanding phylogenetic relationships [5]. Here we document surprising results revealing a case in which inferences regarding the validity of a potentially extinct and iconic species of Neotropical bird were likely compromised because within-species variation was not accounted for in phylogenetic analyses evaluating the alternative hypothesis that the only known specimen may represent a hybrid as opposed to a distinct species.

Hummingbirds (Trochilidae) are well known for their propensity to hybridize, with numerous documented records of interspecific hybridization, often involving species in different genera [6, 7]. Hybrid hummingbird specimens are particularly common in natural history collections and have caused substantial taxonomic confusion because they were often described as distinct species by museum-based ornithologists. Therefore, stringent protocols have been established 
to diagnose hybrid hummingbird specimens and thus avoid treating hybrids as taxa [8]. The application of such protocols has resulted in the diagnosis of numerous hybrids and, consequently, in the consideration of a large number of named species as invalid. For example, G. R. Graves has authored no less than 17 papers on hybrid hummingbird diagnoses since he first described his approach [8] until the present [9].

A notable exception to situations in which historical hummingbird specimens were described as distinct species but were later determined to be hybrids is that of an atypical skin purchased in 1909 by Brother Nicéforo María in Bogotá, Colombia, which was later sent to the Philadelphia Academy of Natural Sciences. Upon examining this specimen, which had puzzled ornithologists for decades and lacked precise locality data, Graves [10] concluded that it was not an aberrant individual of a known taxon and ruled out the possibility that it may represent a hybrid. Therefore, he designated the specimen as the holotype of a new species, the Bogota Sunangel (Heliangelus zusii), which he described while noting it may well have gone extinct due to habitat destruction, representing a "relic of a lost world" [10]. Despite the careful consideration and rejection of alternative hypotheses for what this specimen might represent [10], its description as a new species was received with skepticism by some researchers [11].

A study analyzing mitochondrial DNA (mtDNA) sequence data for the only known specimen of $H$. zusii largely settled disagreements about its validity as a species [12]. Phylogenetic analyses remarkably indicated that the specimen is not closely related to species of Heliangelus; rather, it was found to be included in a clade with two species in the genus Aglaiocercus from northern South America (Long-tailed Sylph A. kingii and Violet-tailed Sylph A. coelestis) and the Gray-bellied Comet (Taphrolesbia griseiventris), a species in a monotypic genus endemic to semiarid scrub habitats in north-central Peru [12]. In addition, sequence divergence between the H. zusii holotype and specimens of Aglaiocercus and Taphrolesbia was considered substantial ( $>5 \%$ and $3 \%$ p-distance, respectively), validating its status as a distinct species [12]. Accordingly, the South American Classification Committee of the American Ornithological Society presently treats $H$. zusii as valid species [13].

In 2011, news about observations of a striking hummingbird in montane forests of the Reserva Rogitama, located in the Eastern Cordillera of the Andes in departamento Boyacá, Colombia, produced great excitement among ornithologists and birding enthusiasts, who suspected it might correspond to $H$. zusii. However, after careful examination of a single individual that was captured and released, it was concluded that the Rogitama hummingbird was not $H$. zusii; rather, various phenotypic characters suggested that it was a hybrid, with A. kingii and Tyrian Metaltail (Metallura tyrianthina) hypothesized to be its most likely parents [14]. Given clarity about the identity of the Rogitama bird, $H$. zusii remains a lost taxon with no records other than the type specimen and is considered critically endangered if not already extinct $[15,16]$.

Intrigued by the finding of the Rogitama bird, we obtained mtDNA sequence data from a feather sample of it to compare it with data from other hummingbird taxa. Upon initial analyses, we were struck to find that the sequence we obtained was remarkably similar to the published sequence of $H$. zusii available in GenBank [12] in the relatively few nucleotide positions in which they overlapped. Considering that phenotypic traits clearly indicate that the Rogitama bird is not $H$. zusii, we began to entertain a new hypothesis, namely that both of these birds are indeed hybrids, with their similar mtDNA indicating a shared maternal species. Our ongoing work on the phylogeography of $A$. kingii, one of the hypothesized parental species of the Rogitama hummingbird [14], allowed us to compare sequences of this species from various regions with those of the Rogitama hummingbird, the holotype of $H$. zusii, and other closely related hummingbird taxa to evaluate this hypothesis.

\section{MATERIAL AND METHODS}

Detailed analyses of the phylogeny and phylogeography of Aglaiocercus and near relatives will be published elsewhere. For the purpose of this study, we sequenced the ND2 mitochondrial gene (ND2) for 32 individuals of $A$. kingii and two of $A$. coelestis. Sampling was designed to cover the distribution range of $A$. kingii, but was especially thorough in montane regions of Colombia, considering the geographic origin of the Rogitama hummingbird and, hypothetically, of H. zusii (Figure 1a, Appendix A). Details about the laboratory methods are described in the electronic supplementary 
material. We combined our new data with published sequences of H. zusii (GenBank Accession GU166851), T. griseiventris (GU166856), Adelomyia melanogenys (JF894047), and Chalcostigma herrani (EU042536), with the latter two species designated as outgroups $[12,17]$. New sequences were deposited in GenBank (accession numbers XXXXXXXX). Because we were unable to obtain complete ND2 sequences for the Rogitama hummingbird (we obtained 543 base pairs) and the available ND2 sequence of $H$. zusii is also incomplete, overlap in sequence data between these two specimens was restricted only to 71 base pairs. Overlap with sequences of other specimens, however, was much more extensive.

We estimated ND2 gene trees using maximum likelihood and Bayesian inference methods. Maximum-likelihood reconstructions were conducted in RAxML-HPC version 8 [18] on XSEDE; we calculated nodal support using 1000 pseudoreplicates using the CIPRES Science Gateway [19]. The Bayesian analysis was carried out using MrBayes v.3.2.6 [20]. We ran four independent runs consisting of four MCMC chains for 10 million generations sampling every 1000 generations, discarding the first $25 \%$ of the sampled trees as burn in. We implemented a general-time reversible model of nucleotide substitution with gamma-distributed rate heterogeneity among sites $(\mathrm{GTR}+\mathrm{G})$ in both analyses as selected using the Akaike Information Criterion in jModelTest [21].

\section{RESULTS AND DISCUSSION}

Mitochondrial DNA data indicate that A. kingii exhibits considerable population structure, with distinct lineages occupying different regions in its distribution range (Figure 1b). We found that sequences of the holotype of $H$. zusii and the Rogitama hummingbird are nested within Aglaiocercus, where they clearly belong in a clade formed by individuals of $A$. kingii from the three Cordilleras of the Colombian Andes. Sequences of both "problem" birds are most similar to sequences of individuals from the Eastern Cordillera. In fact, the ND2 sequence of the holotype of $H$. zusii (181 bp) is identical to a sequence of $A$. kingii from Huila (IAvH BT1210; Appendix A) and differs in only one nucleotide from sequences of $A$. kingii from Santander and Norte de Santander (Appendix A). Likewise, the ND2 sequence of the Rogitama hummingbird is identical to sequences observed in individuals from Huila, Santander and Norte de Santander (Colombia), and in individuals from eastern Ecuador and Peru. Indeed, the sequences of H. zusii and of the Rogitama hummingbird are identical along the 71 nucleotide sites in which they overlap. Because of the short available sequences of both H. zusii and the Rogitama hummingbird, we also analyzed the data considering only the 181 bp fragment we had from H. zusii ND2, and results were the same. Phylogenetic analyses of the mtDNA data, however, were unable to recover relationships among clades of $A$. kingii with strong support: major clades formed a polytomy with sequences of $A$. coelestis and T. griseiventris, revealing a more complex pattern than suggested by previous phylogenetic studies $[12,17]$.

We interpret the above the results to imply that, contrary to current views, the holotype of $H$. zusii is probably not a representative of a valid species. Rather, it is most likely a hybrid; because mtDNA is maternally inherited, the data suggest it resulted from a cross between a female A. kingii and another species of hummingbird. Given the phylogeographic pattern observed, this hybridization event most likely took place in the Eastern Cordillera of the Colombian Andes. Thus, in addition to resolving the status of an enigmatic specimen, our analysis helps to partly clarify its geographic provenance, considering that "Bogota" trade skins may originate from multiple geographic areas in northern South America [22]. Our results also confirm the hypothesis that the hybridization event producing the Rogitama hummingbird involved a female A. kingii [14]. The phenotypic differences between the $H$. zusii and the Rogitama hummingbird suggest that although they share A. kingii as female parent they were likely sired by males of different species. However, the observation of phenotypic characters not present in either parental species as shown by recent studies of vocalizations [14] and plumage [23] makes hybrid diagnosis in hummingbirds especially complicated. In fact, our findings underscore the difficulty of diagnosing hummingbird hybrids using phenotypic characters even when rigorous protocols are employed $[8,10]$. We thus suggest that analyses of sequences of nuclear genes from the holotype of $H$. zusii would be necessary to establish its other parental species with certainty.

To conclude, we note that our inferred phylogenetic relationships are entirely consistent with those inferred in the study concluding that $H$. zusii is a valid taxon [12], with the radically different conclusion we reached becoming evident only because of our increased taxonomic and geographic sampling. Specifically, because the authors of the earlier study 
sampled a single individual per species of Aglaiocercus (see also [17]), they were unable to detect that $H$. zusii has Aglaiocercus mtDNA and to uncover the complex pattern of genealogical relationships among populations of $A$. kingii and with respect to other Aglaiocercus and Taphrolesbia. Given the unexpected findings of this study and results of other analyses [e.g. 5, 24, 25], we stress that addressing questions about the phylogeny and phylogeography of Neotropical birds - even in cases involving questions about the affinities of a single specimen- requires comprehensive sampling across taxonomy and geography, including multiple individuals per taxon and region.

\section{Acknowledgements}

We thank Roberto Chavarro for permission to obtain feather samples of the Rogitama hummingbird in his reserve and to F. Gary Stiles for providing such samples. We thank the following museums for providing samples for this study: Colección Ornitológica Phelps, Instituto Alexander von Humboldt, Instituto de Ciencias Naturales Colombia, Museo de Zoología of the Universidad Católica del Ecuador, Louisiana State University Museum of Natural Science, and Museum of Southwestern Biology University of New Mexico. Funding was provided by the Consejo de Desarrollo Científico y Humanístico de la Universidad Central de Venezuela (JPE) and University of New Mexico (CW). We thank the national authorities of Colombia and Venezuela for granting research permits. We thank Elisa Bonaccorso for providing sequences of Ecuadorian material and J. Miranda and M. Castro for help with laboratory work. The manuscript was improved thanks to comments by Gary R. Graves.

[1] Zwickl, D.J. \& Hillis, D.M. 2002 Increased taxon sampling greatly reduces phylogenetic error Systematic Biology $51,588-598$.

[2] Buckley, D. 2009 Toward an organismal, integrative, and iterative phylogeography. BioEssays 31, $784-793$.

[3] Ahrens, D., Fujisawa, T., Krammer, H.-J., Eberle, J., Fabrizi, S. \& Vogler, A.P. 2016 Rarity and incomplete sampling in DNA-based species delimitation. Systematic Biology 65, 478-494.

[4] Turchetto-Zolet, A.C., Pinheiro, F., Salgueiro, F. \& Palma-Silva, C. 2013 Phylogeographical patterns shed light on evolutionary process in South America. Molecular Ecology 22, 1193-1213.

[5] Avendaño, J.E., Arbeláez-Cortés, E. \& Cadena, C.D. 2017 On the importance of geographic and taxonomic sampling in phylogeography: A reevaluation of diversification and species limits in a Neotropical thrush (Aves, Turdidae). Molecular Phylogenetics and Evolution 111, 87-97.

[6] McCarthy, E.M. 2006 Handbook of avian hybrids. New York, Oxford University Press.

[7] Banks, R.C. \& Johnson, N.K. 1961 A review of North American hybrid hummingbirds. Condor 63, 3-28.

[8] Graves, G.R. 1990 Systematics of the "green-throated sunangels" (Aves: Trochilidae): valid taxa or hybrids? Proceedings of the Biological Society of Washington 103, 6-25.

[9] Graves, G.R., Dittmann, D.L. \& Cardiff, S.W. 2016 Diagnoses of hybrid hummingbirds (Aves: Trochilidae). 17. Documentation of the intrageneric hybrid (Archilochus colubris x Archilochus alexandri). Proceedings of the Biological Society of Washington 129, 1-9.

[10] Graves, G.R. 1993 Relic of a lost world: a new species of sunangel (Trochilidae: Heliangelus) from "Bogotá". Auk $110,1-8$.

[11] Schuchmann, K.-L. 1999 Hummingbirds. In Handbook of the Birds of the World. Volume 5: Barn-owls to Hummingbirds (eds. J. del Hoyo, A. Elliot \& D. Christie), pp. 468-680. Barcelona, Lynx Edicions.

[12] Kirchman, J.J., Witt, C.C., McGuire, J.A. \& Graves, G.R. 2010 DNA from a 100-year-old holotype confirms the validity of a potentially extinct hummingbird species. Biology Letters 6, 112-115.

[13] Remsen, J.V., Jr., Areta, J.I., Cadena, C.D., Claramunt, S., Jaramillo, A., Pacheco, J.F., Pérez-Emán, J., Robbins, M.B., Stiles, F.G., Stotz, D.F., et al. 2017 A classification of the bird species of South America, version [date], American Ornithologists' Union. http://www.museum.lsu.edu/ Remsen/SACCBaseline.htm.

[14] Stiles, F.G. \& Cortés-Herrera, J.O. 2015 Diagnosis and observations of a hybrid hummingbird (Metallura tyrianthina x Aglaiocercus kingi) in the Eastern Andes of Colombia. Revista de la Academia Colombiana de Ciencias Exactas, Físicas y Naturales 39, 481-490.

[15] Parra, J.L. 2016 Heliangelus zusii. In Libro rojo de aves de Colombia, Volumen II: Ecosistemas abiertos, secos, insulares, acuáticos continentales, marinos, tierras altas del Darién y Sierra Nevada de Santa Marta y bosques 
húmedos del centro, norte y oriente del país (eds. L.M. Renjifo, A.M. Amaya-Villareal, J. Burbano-Girón \& J. Velásquez-Tibatá), p. 192. Bogotá, Colombia, Universidad Javeriana e Instituto Alexander von Humboldt. [16] Renjifo, L.M., Amaya-Villareal, A.M., Burbano-Girón, J. \& Velásquez-Tibatá, J. 2016 Libro rojo de aves de Colombia, Volumen II: Ecosistemas abiertos, secos, insulares, acuáticos continentales, marinos, tierras altas del

Darién y Sierra Nevada de Santa Marta y bosques húmedos del centro, norte y oriente del país. Bogotá, Colombia, Universidad Javeriana e Instituto Alexander von Humboldt. Molecular phylogenetics and the diversification of hummingbirds. Current Biology 24, 910-916.

[18] Stamatakis, A. 2014 RAxML version 8: a tool for phylogenetic analysis and post-analysis of large phylogenies. Bioinformatics 30, 1312-1313.

[19] Miller, M.A., Preiffer, W. \& Schwartz, T. 2010 Creating the CIPRES Science Gateway for inference of large phylogenetic trees. (pp. 1-8. New Orleans, LA, Proceedings of the Gateway Computing Environments Workshop (GCE), 14 Nov. 2010.

[20] Ronquist, F., Teslenko, M., van der Mark, P., Ayres, D.L., Darling, A., Höhna, S., Larget, B., Liu, L., Suchard, M.A. \& Huelsenbeck, J.P. 2012 MrBayes 3.2: efficient Bayesian phylogenetic inference and model choice across a large model space. Systematic Biology 61, 539-542.

[21] Posada, D. 2008 jModelTest: phylogenetic model averaging. Molecular Biology and Evolution 25, $1253-1256$. [22] Quintero Toro, C. 2012 Birds of empire, birds of nation: A history of science, economy, and conservation in United States-Colombia relations. (Bogotá, Colombia, Universidad de los Andes.

[23] Clark, C.J., Feo, T.J. \& van Dongen, W. 2013 Sounds and courtship displays of the Peruvian Sheartail, Chilean Woodstar, Oasis Hummingbird, and a hybrid male Peruvian Sheartail × Chilean Woodstar. Condor 115, 560-577.

[24] Avendaño, J.E., Barker, F.K. \& Cadena, C.D. 2016 The Yellow-green Bush-tanager is neither a bush-tanager nor a sparrow: Molecular phylogenetics reveals that Chlorospingus flavovirens is a tanager (Aves: Passeriformes; Thraupidae). Zootaxa 4136, 373-381.

[25] Zucker, M.R., Harvey, M.G., Oswald, J.A., Cuervo, A., Derryberry, E. \& Brumfield, R.T. 2016 The Mousecolored Tyrannulet (Phaeomyias murina) is a species complex that includes the Cocos Flycatcher (Nesotriccus ridgwayi), an island form that underwent a population bottleneck. Molecular Phylogenetics and Evolution 101, 294302. 

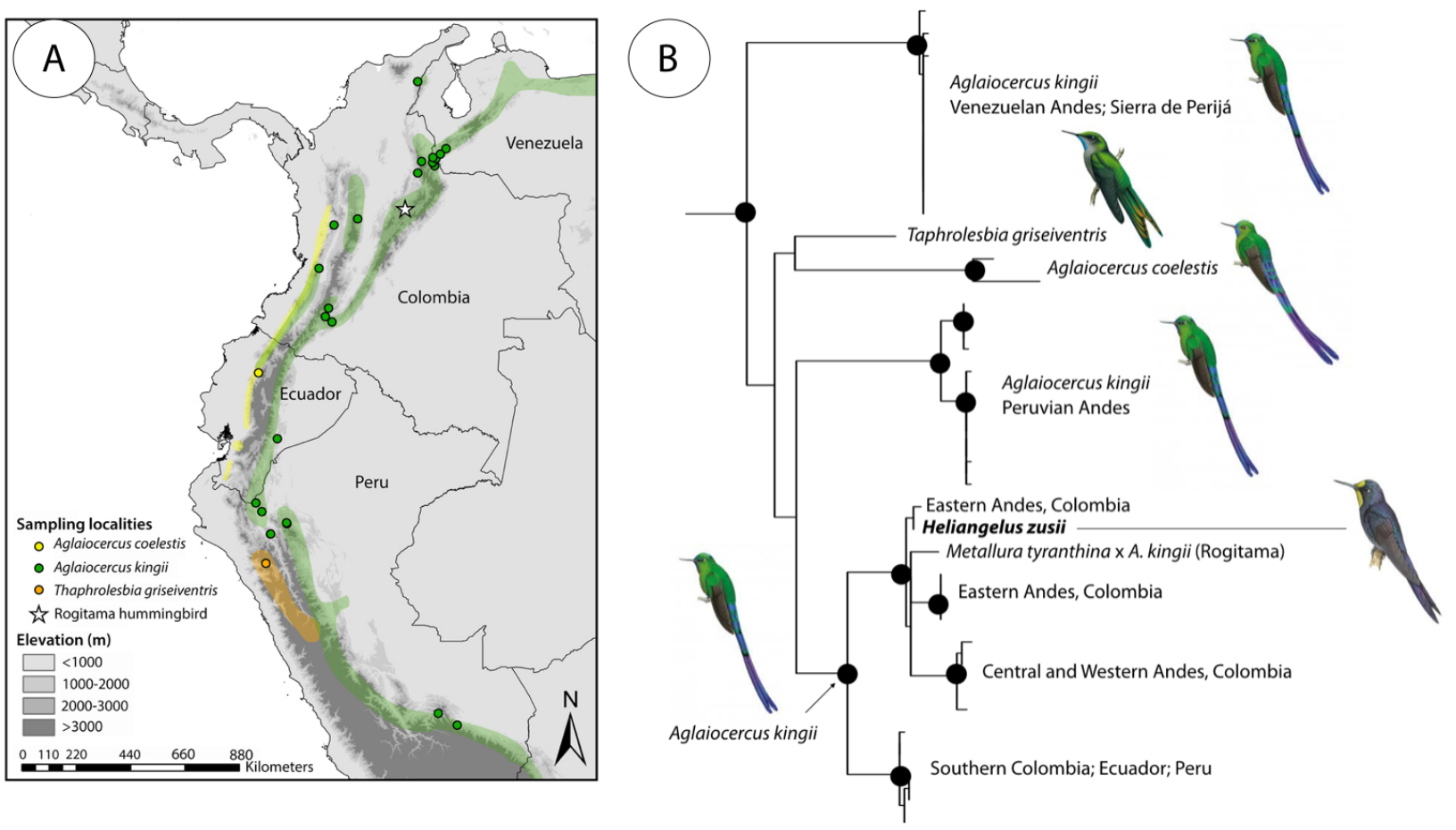

Figure 1. (A) Geographic ranges of Aglaiocercus kingii, A. coelestis, and Taphrolesbia griseiventris in northern South America (polygons), and geographic provenance of specimens of these species and of the Rogitama hybrid hummingbird included in molecular phylogenetic analyses (dots and star). (B) Phylogenetic relationships among species and populations of Aglaiocercus, Taphrolesbia, the Rogitama hybrid hummingbird, and Heliangelus zusii based on sequences of the ND2 mitochondrial gene. Strongly supported nodes (0.95 Bayesian posterior probability, 80\% maximum-likelihood bootstrap) are indicated with black dots. Although nodal support for deep branches is low, note that both the Rogitama bird and H. zusii have haplotypes closely allied to those of A. kingii from the Eastern Andes of Colombia, indicating they are both hybrids sharing $A$. kingii as female parent. Illustrations courtesy of Lynx Edicions; Handbook of the Birds of the World, Vol. 15, 1999. 
Appendix A

Tissue samples sequenced in this study for the mitochondrial ND2 gene. Collection acronyms: Colección Ornitológica Phelps (COP), Instituto Alexander von Humboldt (IAvH), Instituto de Ciencias Naturales Colombia (ICN), Museo de Zoología of the Universidad Católica del Ecuador (QCAZ), Louisiana State University Museum of Natural Science (LSUMNH), Museum of Southwestern Biology University of New Mexico (MSB).

\begin{tabular}{|c|c|c|}
\hline Taxon & Catalog number & Locality \\
\hline Aglaiocercus kingii & COP (JM1113) & Venezuela, Táchira, P. N. El Tamá \\
\hline Aglaiocercus kingii & COP (YPL205) & Venezuela, Táchira, P. N. El Tamá \\
\hline Aglaiocercus kingii & COP (YPL226) & Venezuela, Táchira, P. N. El Tamá \\
\hline Aglaiocercus kingii & COP (YPL233) & Venezuela, Táchira, P. N. El Tamá \\
\hline Aglaiocercus kingii & COP (JM1053) & Venezuela, Táchira, P. N. Chorro El Indio \\
\hline Aglaiocercus kingii & COP (YPL121) & Venezuela, Táchira, P. N. Páramos El Batallón y La Negra \\
\hline Aglaiocercus kingii & ICN $37200($ JPL255) & Colombia, Cesar, Manaure \\
\hline Aglaiocercus kingii & IAvH (SS1172) & Colombia, Casanare, Orocué \\
\hline Aglaiocercus kingii & IAvH (SS1252) & Colombia, Casanare, Orocué \\
\hline Aglaiocercus kingii & IAvH (AMC1018) & Colombia, Norte de Santander, Asiria \\
\hline Aglaiocercus kingii & IAvH BT1780 & Colombia, Norte de Santander, Cucutilla \\
\hline Aglaiocercus kingii & IAvH BT1831 & Colombia, Norte de Santander, Cucutilla \\
\hline Aglaiocercus kingii & IAvH BT5331 & Colombia, Santander, Piedecuesta \\
\hline Aglaiocercus kingii & IAvH BT1210 & Colombia, Huila, Acevedo, camino al pesebre \\
\hline Aglaiocercus kingii & IAvH BT2330 & Colombia, Huila, P. N. Puracé \\
\hline Aglaiocercus kingii & IAvH BT7358 & Colombia, Huila, San Agustín, Reserva Natural Los Yalcones \\
\hline Aglaiocercus kingii & IAvH BT2435 & Colombia, Valle, La Cumbre, cuenca alta del río Bitaco \\
\hline Aglaiocercus kingii & $\mathrm{IAvH} \mathrm{BT2450}$ & Colombia, Valle, La Cumbre, cuenca alta del río Bitaco \\
\hline Aglaiocercus kingii & IAvH BT4070 & Colombia, Risaralda, Pueblo Rico, P. N. Tatáma \\
\hline Aglaiocercus kingii & IAvH BT4673 & Colombia, Caldas, La Miel \\
\hline Aglaiocercus kingii & LSUMNH B6216 & Ecuador, Morona Santiago, W slope cordillera del Cutucú \\
\hline Aglaiocercus kingii & LSUMNH B34830 & Perú, Cajamarca, Cordillera del Condor, Picorana \\
\hline Aglaiocercus kingii & LSUMNH 33579 & Perú, Cajamarca, Nuevo Perú \\
\hline Aglaiocercus kingii & MSB:Bird:32143 & Perú, Amazonas, $4.5 \mathrm{~km} \mathrm{~N}$ Tullanya \\
\hline Aglaiocercus kingii & MSB:Bird:32885 & Perú, Amazonas, $4.5 \mathrm{~km} \mathrm{~N}$ Tullanya \\
\hline Aglaiocercus kingii & MSB:Bird:32887 & Perú, Amazonas, $4.5 \mathrm{~km} \mathrm{~N}$ Tullanya \\
\hline Aglaiocercus kingii & LSUMNH 44328 & Perú, San Martín, ca 22 km ENE Florida \\
\hline Aglaiocercus kingii & LSUMNH B44400 & Perú, San Martín, ca 22 km ENE Florida \\
\hline Aglaiocercus kingii & LSUMNH B44447 & Perú, San Martín, ca 22 km ENE Florida \\
\hline Aglaiocercus kingii & MSB:Bird:27271 & Perú, Cusco, San Pedro \\
\hline Aglaiocercus kingii & MSB:Bird:33213 & Perú, Cusco, Abra Bella Vista \\
\hline Aglaiocercus kingii & MSB:Bird:33250 & Perú, Cusco, Abra Bella Vista \\
\hline Aglaiocercus coelestis & QCAZ (CARS159) & Ecuador, Pichincha, Estación Científica Río Guajalito (1900 m) \\
\hline Aglaiocercus coelestis & QCAZ (CARS168) & Ecuador, Pichincha, Estación Científica Río Guajalito (1900 m) \\
\hline
\end{tabular}

Laboratory Methods

We isolated whole genomic DNA using the Dneasy Tissue Kit (Qiagen, Valencia, California) following manufacturer's instructions or a phenol-chloroform method. Amplification of the subunit 2 of the proteing-coding gene NADH (ND2, $1041 \mathrm{bp}$ ) was done using the polymerase chain reaction (PCR) in a 2720 termocycler (Applied Biosystems) and primers 
L5219 and H6313 (Sorenson et al 1999). PCR conditions included an initial denaturation at $95^{\circ} \mathrm{C}$ for 8 min, followed by 35 cycles of denaturation at $95^{\circ} \mathrm{C}$ for $30 \mathrm{~s}$, annealing at $50^{\circ} \mathrm{C}$ for $30 \mathrm{~s}$, and an extension phase of $72^{\circ} \mathrm{C}$ for $60 \mathrm{~s}$. These cycles were ended with a final extension phase of $72^{\circ} \mathrm{C}$ for $10 \mathrm{~m}$. The PCR reactions contained 1-2 $\mu \mathrm{L}$ of DNA template, $0.125 \mathrm{U}$ of $\mathrm{Taq}$ polymerase (PROMEGA), $14.375 \mu \mathrm{L} \mathrm{H} 20,1.5 \mu \mathrm{L} \mathrm{MgCl} 2,5 \mu \mathrm{L}$ buffer solution, $1.25 \mu \mathrm{L}$ of each primer, and $0.5 \mu \mathrm{L}$ dNTPs, in a total volume of $25 \mu \mathrm{L}$. These PCR products were purified in a $1 \%$ low-melting point agarose gels and cycle-sequenced using $1 \mu \mathrm{L}$ DNA template. Molecular work with the Rogitama hummingbird was conducted in a separate lab at Universidad de los Andes and the data for H. zusii were obtained from the literature, implying that contamination of samples is not a plausible explanation for our results. 